\title{
The Relationship of the Enterobacterium A12 (Sachs) to Shigella boydii 14
}

\author{
BY K. PATRICIA CARPENTER \\ Dysentery Reference Laboratory, Central Public Health Laboratory, \\ Colindale Avenue, London, N.W. 9
}

(Received 3 May 1961)

\section{SUMMARY}

The relationship of the enterobacterium A12 (Sachs) to Shigella boydii 14 is shown by comparison of their biochemical and serological reactions. The aerogenic, mannitol-negative A12 is serologically identical with the typical Shigella serotype, $S$. boydii 14. As mannitol-negative strains of $S$. boydii 14 exist and as the aerogenic A12 organism is otherwise biochemically typical of the Shigella group, it is proposed that $\mathrm{A12}$ be regarded as a biochemical variety of $S$. boydii 14 analogous to the accepted aerogenic biochemical varieties of $S$. flexneri 6 .

\section{INTRODUCTION}

It is well known that there is a wide sharing of antigens throughout the whole family of the Enterobacteriaceae so that the determination of the antigenic structure of a particular enterobacterium is only one part of the jigsaw of identification and subsequent classification. The identification of these organisms must, at least at present, be based on both biochemical and serological criteria. Even so bacteriologists constantly encounter organisms which cannot easily be placed in one or other of the groups of the Enterobacteriaceae, whose main subdivisions, with the increasing use of the more detailed biochemical tests, are now reasonably well defined.

The aerogenic enterobacterium A12 of Sachs (1943) is an example of an intestinal organism whose exact taxonomic position within the Enterobacteriaceae is still not finally determined. Sachs considered this organism a possible member of the nonmannitol-fermenting subgroup of Shigella, whereas Ewing \& Hucks (1950) considered it an aberrant coliform of the Escherichia coli $O$ group 32. Wheeler \& Stuart (1946) also discussed A12 and though, in the light of available knowledge at that time, they considered that the organism should not be included in the Shigella group, they did suggest that if a serological relationship to other strains of shigella was shown in time and if anaerogenic variants could be produced from it then there would be good reason to include it in the Shigella group. These authors drew attention to a similar situation occurring in the biochemical varieties of the NewcastleManchester-Boyd 88 dysentery bacilli. This opinion has now been fully justified with further knowledge and it is suggested that the position of A12 can be opportunely reviewed. It is proposed that this organism be regarded as a biochemical variety of the serotype $S$. boydii 14 . 


\section{SOURCE OF ORGANISMS}

There seem to be few records in the literature of the isolation of A12 from either single cases or outbreaks. In the first description of the organism Sachs examined 10 strains isolated in military laboratories on the North West Frontier of India between 1936 and 1941. The single A 12 strain examined by Wheeler \& Stuart was one of Sachs original strains and Ewing \& Hucks strains are described as 'representative cultures', but these authors make no mention of freshly-isolated strains. Since the establishment of the Dysentery Reference Laboratory in 194521 strains of A 12, freshly isolated in this country, have been identified. One strain was isolated in 1953 from a 14-year-old girl who had just arrived from the Sudan suffering from diarrhoea and from whom Salmonella uganda had also been isolated. Nineteen strains had been isolated during an outbreak of dysentery in a mental hospital in $1957 ; 16$ of these strains were isolated from elderly female patients with acute diarrhoea, 1 from a 37-year-old patient who was herself probably infected in India and who undoubtedly introduced the infection to the hospital, and 2 were isolated from symptomless excreters (Dr H. I. Coombs, personal communication). One further strain was isolated from a 21-year-old male laboratory technician suffering from acute dysentery whose infection was acquired in the laboratory during the investigation of the 19 mental hospital strains.

\section{METHODS}

Strains. These 21 freshly isolated strains and the stock laboratory culture originally received from Sachs were available for detailed study in comparison with Shigella boydii 14. Six strains of $S$. boydii 14 were available and all have been received from Dr W. H. Ewing (Communicable Disease Centre, Atlanta, Georgia, U.S.A.) over the years 1952-57. Three strains of Escherichia coli $\mathrm{O}$ group 32 were also received trom Dr Ewing.

\section{Biochemical tests}

Fermentation tests. Carbohydrates $(0.5 \%, w / v)$ in $1 \%(w / v)$ peptone water with Andrade indicator, observed for 21 days.

Urease. Christensen (1946).

$\mathrm{H}_{2} \mathrm{~S}$ production. (1) Lead acetate papers over nutrient broth; (2) Triple Sugar Iron Agar (Test 10, Report, 1958a).

Phenylpyruvic acid test. (1) Henriksen (1950); (2) combined with malonate (Shaw \& Clarke, 1955); (3) phenylalanine agar (Test 18, Report, 1958a).

Methyl red $(M R)$ and Voges-Proskauer (VP) tests. Incubation for 5 days at $30^{\circ}$; VP test (O'Meara, 1931).

Citrate utilization. (1) Koser (1923); (2) Simmons (1926); (3) Christensen (1949) as modified by Fdwards \& Fwing (1955).

Malonate test. Combined with phenylanine, Shaw \& Clarke (1955).

Gluconate test. Shaw \& Clarke (1955) modified by using 'Clinitest' Reagent Tablets (Ames Company, Nuffield House, London, W. 1) in place of Benedict qualitative solution.

Gelatine liquefaction. Nutrient gelatine stab culture incubated for 42 days at room temperature (about $\mathbf{2 2}^{\circ}$ ).

Growth in $K C N$. Møller (1954) modified by using bijou bottles with the caps very tightly screwed. 
Nitrate reduction. (1) $0 \cdot 1 \%(\mathrm{w} / \mathrm{v})$ nitrate broth, tested after 5 days of incubation by Griess-Ilosvay method (Topley and Wilson's Principles, 1955); (2) plate test, Cook (1950).

Decarboxylases. Møller (1955).

Indole. $2 \%(\mathrm{w} / \mathrm{v})$ peptone water, (1) tested after 24 and $48 \mathrm{hr}$. with Kovacs reagent (1928); (2) oxalic acid papers (Holman \& Gonzales, 1923).

Except as indicated, the temperature of incubation was $35^{\circ}$.

\section{Serological tests}

The antigen suspensions used were prepared in mercuric iodide solution (Bridges, 1951) from meat digest agar slopes and as necessary heated in a boiling water bath for $30 \mathrm{~min}$. The several A 12 and Shigella boydii 14 antisera used were prepared at the Dysentery Reference Laboratory. The two Escherichia coli $\mathbf{O}$ group 32 antisera used were kindly supplied by Dr W. H. Ewing and by Dr J. F. Winn (Communicable Disease Center, Atlanta, Georgia, U.S.A.). Tube agglutination tests were performed by a Dreyer technique and incubated in a $50^{\circ}$ water bath for $4 \mathrm{hr}$, read, and incubated further overnight. All tests were done in duplicate with unheated and heated suspensions.

\section{RESULTS}

General characters. The $\mathbf{A} 12$ organisms are Gram-negative rods, non-sporing and non-acid-fast, indistinguishable in size and appearance from classical shigellas. Capsules have not been demonstrated. They are facultative aerobes and give characteristic shigella-like colonies on the usual 'enteric' media and, like shigellas, they do not grow on bismuth sulphite (Wilson \& Blair) agar. Growth in broth and peptone water closely resembles that of accepted shigellas in showing a fairly clear supernatant fluid and a light powdery deposit, quite different from the denser uniform turbidity characteristic of the Escherichia, Hafnia or Salmonella groups.

\section{Biochemical reactions}

Table 1 summarizes the biochemical reactions of A12 and Shigella boydii 14. The volume of gas produced by the $A 12$ strains from glucose occupied about $\frac{1}{4}-\frac{1}{3}$ of the Durham tube; Sachs original strain produced less than the others but it is now an old laboratory culture. In general, only a tiny amount of gas, less than $\frac{3}{4}$ of the Durham tube, was produced from maltose. There was some minor strain variation in the period of incubation required for the fermentation of certain carbohydrates, but the average was fairly consistent. Xylose was generally fermented after incubation for 6 days, dextrin after 5 days, glycerol after 2 days and maltose after 5 days. Sorbitol was rapidly fermented, usually after 1-2 days. Dextrin was the most irregularly fermented carbohydrate. One of the A12 strains and two of the $S$. boydii 14 strains did not ferment it and most of the strains tested produced less than full acidity from it. On testing in Hugh \& Leifson (1953) medium all strains showed fermentative metabolism.

Attempts were made by multiple colony selection to find anaerogenic colonies from the aerogenic strains. Though several colonies were found to produce only a tiny bubble of gas no colony failed to produce some gas from glucose.

Apart from the production or otherwise of gas, and the fermentation of mannitol 
or otherwise, it is clear that the reactions of the $\mathbf{A} 12$ organisms and Shigella boydii 14 are identical. None of the $\mathbf{A 1 2}$ strains shows any biochemical reaction which would eliminate them from the Shigella group as at present defined (Report, 1958a).

Table 1. Biochemical reactions

\begin{tabular}{|c|c|c|c|c|}
\hline & & & S. bo & 14 \\
\hline & $\begin{array}{l}\text { Sachs } \\
\text { original } \\
\text { strain }\end{array}$ & $\begin{array}{l}\text { D.R.I. } \\
21 \text { strains }\end{array}$ & 4 strains & 2 strains \\
\hline Glucose & $\mathbf{A G}$ & $\mathbf{A G}$ & $\mathbf{A}$ & $\mathbf{A}$ \\
\hline Lactose & - & - & - & - \\
\hline Mannitol & - & - & $\mathbf{A}$ & - \\
\hline Sucrose & - & - & - & - \\
\hline Dulcitol & - & - & - & - \\
\hline Salicin & - & - & - & - \\
\hline Xylose & $(\mathrm{Ag})$ & $(\mathbf{A G})$ & (A) & (A) \\
\hline Adonitol & - & - & - & - \\
\hline Arabinose & $\mathbf{A}$ & $\mathbf{A G}$ & $\mathbf{A}$ & $\mathbf{A}$ \\
\hline Cellobiose & - & - & - & - \\
\hline Dextrin & (a) & (a) $/-$ & $-/(a)$ & (A) \\
\hline Glycerol & (A) & (A) & (A) & (A) \\
\hline Inositol & - & - & - & - \\
\hline Maltose & (Ag) & (Ag) & (A) & (A) \\
\hline Raffinose & - & - & - & - \\
\hline Rhamnose & - & - & - & - \\
\hline Sorbitol & $(\mathbf{A G})$ & $(\mathbf{A G})$ & $\mathbf{A}$ & $\mathbf{A}$ \\
\hline Trehalose & $\mathbf{A G}$ & $\mathbf{A G}$ & $\mathbf{A}$ & $\mathbf{A}$ \\
\hline Urease production & - & - & - & - \\
\hline $\mathrm{H}_{2} \mathrm{~S}$ production & - & - & - & - \\
\hline Motility & - & - & - & - \\
\hline Indole production & - & - & - & - \\
\hline Phenylpyruvic acid test & - & - & - & - \\
\hline MR reaction & + & + & + & + \\
\hline VP reaction & - & - & - & - \\
\hline Citrate utilization & - & - & - & - \\
\hline Malonate & - & - & - & - \\
\hline Gluconate & - & - & - & - \\
\hline Gelatine liquefaction & - & - & - & - \\
\hline Growth in $\mathrm{KCN}$ & - & - & - & - \\
\hline Nitrate reduction & + & + & + & + \\
\hline Oxidase & - & - & - & - \\
\hline Catalase & + & + & + & + \\
\hline Decarboxylases: & & & & \\
\hline Arginine & - & - & - & - \\
\hline Lysine & - & - & - & - \\
\hline Ornithine & - & - & - & - \\
\hline Litmus milk & No change & No change & No change & No chang \\
\hline
\end{tabular}

$A=$ acid production within $24 \mathrm{hr}$; (A) = acid after $48 \mathrm{hr}$; (a) = weak acid; $G=$ gas 1 or more volume of Durham tube; $g=$ gas less than 1 the volume of Durham tube.

\section{Serological reactions}

In slide agglutination tests, all the strains of A12, Shigella boydii 14 and Escherichia coli $\mathrm{O}$ group 32 examined agglutinated in each of the appropriate antiserums for the three serotypes. None of the A12 or S. boydii 14 strains showed any serological cross-relationship with other members of the Shigella group nor with Alka- 
lescens-dispar $O$ groups 1-4. The tube agglutination and absorption tests are summarized in Table 2.

The mirror absorption tests showed clearly that A12, Shigella boydii 14 and Escherichia coli $\mathrm{O}$ group 32 are serologically identical. This further confirms the work of Ewing \& Hucks (1950) who showed that the somatic antigen of A12 was identical with that of $E$. coli $O$ group 32 and of Ewing (1953) who stated that the then provisional Shigella serotype 2770-51 (now $S$. boydii 14) was identical serologically with $E$. coli $\mathrm{O}$ group 32 .

Table 2. Serological tests

Titres are expressed as \% of homologous titres for simplicity since more than one serum of each type and several strains were used, each serum giving a slightly different homologous titre.

\begin{tabular}{|c|c|c|c|c|}
\hline \multirow[b]{2}{*}{ Antiserum } & \multirow{2}{*}{$\begin{array}{l}\text { Absorbing } \\
\text { suspension }\end{array}$} & \multicolumn{3}{|c|}{ Antigen suspensions } \\
\hline & & A12 & S. boydii 14 & E. coli $\mathbf{O} 32$ \\
\hline A 12 & $\begin{array}{l}- \\
\text { A12 } \\
\text { S. boydii 14 } \\
\text { E. coli } 032\end{array}$ & $\begin{array}{r}100 \\
0 \\
0 \\
0\end{array}$ & $\begin{array}{r}100 \\
0 \\
0 \\
0\end{array}$ & $\begin{array}{r}100 \\
0 \\
0 \\
0\end{array}$ \\
\hline S. boydii 14 & $\begin{array}{l}- \\
\text { A12 } \\
\text { S. boydii } 14 \\
\text { E. coli } 032\end{array}$ & $\begin{array}{r}100 \\
0 \\
0 \\
0\end{array}$ & $\begin{array}{r}100 \\
0 \\
0 \\
0\end{array}$ & $\begin{array}{r}100 \\
0 \\
0 \\
0\end{array}$ \\
\hline E. coli $\mathrm{O}$ group 32 & $\begin{array}{l}- \\
\text { A } 12 \\
S . \text { boydii } 14 \\
\text { E. coli } \mathrm{O} 32\end{array}$ & $\begin{array}{r}100 \\
0 \\
0 \\
0\end{array}$ & $\begin{array}{r}100 \\
0 \\
0 \\
0\end{array}$ & $\begin{array}{r}100 \\
0 \\
0 \\
0\end{array}$ \\
\hline
\end{tabular}

In 1958 the provisional Shigella serotype 2770-51 was accepted as a typical member of the Shigella boydii subgroup and named $S$. boydii 14 (Report, 1958b). Ewing \& Hucks (1952) in describing 2770-51 stated that 'it appears to us to be coincidental that serotype 2770-51 and type A12 (Sachs) both contain O antigens that are identical with those of Escherichia coli O group 32. Culture A12 is considered to be an aberrant intermediate paracolon bacterium because of its biochemical characteristics while serotype $2770-51$ is believed to be a typical Shigella serotype with all the characteristics of $S$. boydii cultures.' They did not, however, consider the possibility that A12 might be a biochemical variety of $S$. boydii 14 . The 2770-51 serotype was further discussed by Ewing, Reavis \& Davis (1958) and they noted that six of their cultures (five from one familial outbreak) did not ferment mannitol.

Within the Shigella group only one member is at present accepted as having aerogenic varieties; this is the serotype Shigella flexneri 6. Scott (Whitehead \& Scott, 1934) showed clearly that the aerogenic 'Newcastle' dysentery bacillus of Clayton \& Warren (1929), the anaerogenic ' 88 ' dysentery bacillus of Boyd (1931) and the aerogenic 'Manchester' bacillus of Downie, Wade \& Young (1933) were serologically identical. The biochemical reactions of this serotype are given in Table 3.

The Newcastle variety, which does not ferment mannitol, may or may not produce gas from glucose; this is like the aerogenic non-mannitol fermenting A12 and the 
anaerogenic non-mannitol fermenting strains of Shigella boydii 14. To date, no strains of $S$. boydii 14 have been found which are both aerogenic and mannitolfermenting, like the Manchester variety of $S$. flexneri 6 . It is generally stated that the characteristic volume of gas produced from glucose by the aerogenic varieties of $S$. flexneri 6 is very small (Topley and Wilson's Principles, 1955) or sometimes described as a tiny bubble. This, however, appears from experience in the Dysentery Reference Laboratory to be no longer true. The aerogenic strains of $S$. flexneri 6 now produce a volume of gas quite as large as that produced by salmonellas. Even the original strains of Clayton \& Warren, and Downie et al., now produce a similar volume in the peptone water media in current use. There is some evidence that the use of modern peptones may influence the volume of gas produced by these organisms. The amount of gas produced by A 12 is very similar to that of the aerogenic strains of $S$. flexneri 6 . Table 4 shows the proposed biochemical varieties of $S$. boydii 14, analogous to those of $S$. flexneri 6.

Table 3. Biochemical reactions of Shigella flexneri 6

$\begin{array}{llclc} & \text { Glucose } & \text { Mannitol } & \text { Dulcitol } & \text { Indole } \\ \text { Boyd's 88 } & \text { A } & \text { A } & \text { A/- } & - \\ \text { Manchester variety } & \text { AG } & \text { AG } & \text { AG/- } & - \\ \text { Newcastle variety } & \text { AG/A } & - & \text { AG/A/- } & -\end{array}$

Fermentation of dulcitol may be delayed.

Table 4. Proposed biotypes of Shigella boydii 14

$\begin{array}{lcccc} & \text { Glucose } & \text { Mannitol } & \text { Dulcitol } & \text { Indole } \\ \text { S. boydii 14 (classical) } & \text { A } & \text { A } & - & - \\ \text { S. boydii 14 (some strains) } & \text { A } & - & - & - \\ \text { A 12 } & \text { Ag } & - & - & -\end{array}$

Pathogenicity. Though pathogenicity may be a poor criterion for taxonomy, the Shigella group as classified at present contains only organisms accepted as pathogenic and as causing bacillary dysentery. There seems to be no reason to exclude the $\mathrm{A} 12$ organism from the bacillary dysentery group. The mental hospital outbreak due to A12 shows that the organism is capable of causing an outbreak of dysentery and, though it might be said that elderly mental hospital patients may be in a special category of susceptibility to such infections, the infection of a young healthy laboratory technician during the handling of the cultures clearly indicates, in the absence of experimental animal infection, that the A12 organism is pathogenic and can produce a clinically typical attack of acute bacillary dysentery exactly similar to that of other shigella infections acquired in the laboratory (K. P. Carpenter, personal observation). Wheeler \& Stuart's criteria in 1946 for acceptance of $\mathrm{Al2}$ as a member of the Shigella group have been fulfilled, and it appears expedient now that Sachs A12 be regarded as a typical aerogenic member of the group and as a biochemical variety of the serotype Shigella boydii 14, exactly analogous to the established biochemical varieties of $S$. flexneri 6 .

I wish to thank my various colleagues who sent me the strains used in this study and in particular, Dr H. I. Coombs. 


\section{REFERENCES}

BoYD, J. S. K. (1931). Some investigations into so-called 'non-agglutinable' dysentery bacilli. J. R. Army med. Cps, 57, 161.

Bridges, R. F. (1951). The Dysentery Reference Laboratory. Brit. med. Bull. 7, 200.

Christensen, W. B. (1946). Urea decomposition as a means of differentiating Proteus and paracolon cultures from each other and from Salmonella and Shigella types. J. Bact. 52, 461.

Christensen, W. B. (1949). Hydrogen sulphide production and citrate utilization in the differentiation of the enteric pathogens and the coliform bacteria. Res. Bull., Weld County Hlth Dept., Colorado, no. 1, 3.

Clayton, F. H. A. \& Warren, S. H. (1929). An unusual bacillus recovered from cases presenting symptoms of dysentery. J. Hyg., Camb. 28, 355.

Cook, G. T. (1950). A plate test for nitrate reduction. J. clin. Path. 3, 359.

Downie, A. W., Wade, E. \& Young, J. A. (1933). An organism resembling the Newcastle type of dysentery bacillus associated with cases of dysentery. J. Hyg., Camb. 33, 196.

Edwards, P. R. \& Ewing, W. H. (1955). Identification of Enterobacteriaceae. Minneapolis: Burgess Publishing Company.

EwING, W. H. \& Hucks, M. C. (1950). Two intermediate members of Enterobacteriaceae. J. Bact. 60, 367.

EwING, W. H. \& Hucks, M. C. (1952). Four new provisional serotypes of Shigella. J. Immunol. 69, 575.

Ewing, W. H. (1953). Serological relationships between Shigella and coliform cultures. J. Bact. 66, 333.

Ewing, W. H., Reavis, R. W. \& Davis, B. R. (1958). Provisional Shigella serotypes. Canad. J. Microbiol. 4, 89.

Henriksen, S. D. (1950). A comparison of the phenylpyruvic acid reaction and the urease test in the differentiation of Proteus from other enteric organisms. J. Bact. 60, 225.

Holman, W. L. \& Gonzales, F. L. (1923). A test for indol based on the oxalic acid reaction of Gnezda. J. Bact. 8, 577.

Hugh, R. \& Leifson, E. (1953). The taxonomic significance of fermentative versus oxidative metabolism of carbohydrates by various Gram-negative bacteria. J. Bact. 66, 24.

Koser, S. A. (1923). Utilization of the salts of organic acids by the coli-aerogenes group. J. Bact. 8, 493.

Kovacs, N. (1928). Eine vereinfachte Methode zum Nachweis der Indolbildung durch Bakterien. Z. ImmunForsch. 55, 311.

MøLler, V. (1954). Diagnostic use of the Braun KCN test within the Enterobacteriaceae. Acta path. microbiol. scand. 34, 115.

Møller, V. (1955). Simplified tests for some amino acid decarboxylases and for the arginine dihydrolase system. Acta path. microbiol. scand. 36, 158.

O'Meara, R. A. Q. (1931). A simple delicate and rapid method of detecting the formation of acetylmethylcarbinol by bacteria fermenting carbohydrate. J. Path. Bact. 34, 401.

Report (1958a). Report of the Enterobacteriaceae Subcommittee of the Nomenclature Committee of the International Association of Microbiological Societies. Int. Bull. bact. Nomencl. 8, 25.

Report (1958b). Supplement to the Third Report on the Shigella group. Report (1958) of the Enterobacteriaceae Subcommittee. Int. Bull. bact. Nomencl. 8, 93.

SACHS, A. (1943). A report on an investigation into the characteristics of new types of non-mannitol-fermenting bacilli isolated from cases of bacillary dysentery in India and Egypt. J. R. Army med. Cps, 80, 92.

Shaw, C. \& Clarke, P. H. (1955). Biochemical classification of Proteus and Providence cultures. J. gen. Microbiol. 13, 155. 
Simmons, J. S. (1926). A culture medium for differentiating organisms of typhoid-colon aerogenes groups and for isolation of certain fungi. J. infect. Dis. 39, 209.

Topley \& Wilson's Principles of Bacteriology and Immunity (1955). 4th ed. Ed. by G. S. Wilson \& A. A. Miles. London: Edward Arnold (Publishers) Ltd.

Wheeler, K. M. \& Stuart, C. A. (1946). The mannitol-negative Shigella group. J. Bact. $51,317$.

Whitehead, H. \& Scott, W. M. (1934). Bacillary dysentery of the Newcastle type. Lancet, ii, 248. 